\title{
Unconventional Neurogenic Niches and Neurogenesis Modulation by Vitamins
}

\author{
Karina Oyarce and Francisco Nualart* \\ Laboratory of Neurobiology and Stem Cells, Center for Advanced Microscopy CMA BIO BIO, Concepcion University, Concepción, Chile
}

\begin{abstract}
Although the generation of new neurons occurs in adult mammals, it has been classically described in two defined regions of the brain denominated neurogenic niches: the subventricular zone of the lateral ventricles and the subgranular zone of the dentate gyrus. In these regions, neural stem cells give rise to new neurons and glia, which functionally integrate into the existing circuits under physiological conditions. However, accumulating evidence indicates the presence of neurogenic potential in other brain regions, from which multipotent precursors can be isolated and differentiated in vitro. In some of these regions, neuron generation occurs at low levels; however, the addition of growth factors, hormones or other signaling molecules increases the proliferation and differentiation of precursor cells. In addition, vitamins, which are micronutrients necessary for normal brain development, and whose deficiency produces neurological impairments, have a regulatory effect on neural stem cells in vitro and in vivo. In the present review, we will describe the progress that has been achieved in determining the neurogenic potential in other regions, known as unconventional niches, as well as the characteristics of the neural stem cells described for each region. Finally, we will revisit the roles of commonly known vitamins as modulators of precursor cell proliferation and differentiation, and their role in the complex and tight molecular signaling that impacts these neurogenic niches.
\end{abstract}

Keywords: Neurogenesis; Neural stem cell; Niche; Differentiation; Vitamins

\section{Introduction}

The continuous generation of new neurons in the mammalian adult brain in discrete regions, called neurogenic niches, has been documented for some time [1-4]. The term "neurogenic niche" is used to define a region in which the cytoarchitecture and signaling factors within its microenvironment are able to maintain a population of neural stem cells (NSCs) with self-renewal capacity that give rise to new neurons and glial cells. Cross-talk between all of the components of the niche is crucial for the survival of NSCs, as well as for controlling their fate [5-7]. By far, the most studied and accepted niches include the subventricular zone (SVZ) of the lateral ventricles and the subgranular zone (SGZ) of the hippocampus dentate gyrus [8-18]. In these classical niches, several key cell types can be recognized, including NSCs that remain mostly in a quiescent state; a transient progenitor cell derived from the NSCs, which have a higher proliferation rate; new immature neurons or glial cells, derived from the progenitor cells; and accessory cells, including parenchymal astrocytes, endothelial, microglial, and ependymal cells, which modulate the niche and are needed for its maintenance [5-7]. In the SVZ niche, differentiated immature neurons migrate to a distant region, the olfactory bulb, where they finally achieve complete differentiation [19-22]. This migration occurs through a restricted path called the rostral migratory stream (RMS). Alternatively, newly generated cells remain in the SGZ niche, renewing neuronal and glial populations near their site of origin [17].

The existence of adult NSCs, which produce new neurons and repair damaged neural circuits, was certainly a breakthrough in neuroscience that provided new opportunities for the development of neural regenerative therapies. However, it was soon recognized that this newly discovered neurogenic potential was present in defined brain regions with restricted neuronal migration.

Whether it is possible to guide their migration and change their destination site remains to be determined. Thus, the search for new neurogenic niches was pursued. To date, there is an increasing amount of evidence suggesting the presence of other niches with neurogenic potential in the adult brain [23-27]. Most of the recently described niches show lower rates of proliferation and differentiation; however, these characteristics can be modulated by several factors, including vitamins, which are micronutrients acquired mostly from the diet.

Vitamin deficiency is known to cause cognitive and learning impairment during early life, and is also associated with neurodegeneration during aging [28-32]. Therefore, vitamins are crucial for both normal development and protection of the brain. In addition, new roles in modulating NSCs and neurogenesis have emerged. In the present review, we will focus on the current knowledge of unconventional neurogenic niches, describing the putative NSCs, their proliferative and differentiation potential and what it is known about their modulation by different factors. Finally, the role of vitamins upon neurogenesis regulation will be discussed.

\section{Studying Adult Neurogenesis}

One of the classic methods used to describe neurogenesis is the presence of proliferative cells as detected by the incorporation of a thymidine analogue, bromodeoxyuridine (BrdU), which labels dividing cells and their progeny over time. The administration form, dosage and time period analyzed after BrdU treatment have proved to be important

*Corresponding author: Francisco Nualart, Laboratory of Neurobiology and Stem Cells, Center for Advanced Microscopy CMA BIO BIO, Concepcion University, Concepción, Chile, Tel: +56--041--2203479; Fax: +56-041-2255479; E-mail: frnualart@udec.cl

Received January 23, 2014; Accepted March 20, 2014; Published March 22 2014

Citation: Oyarce K, Nualart F (2014) Unconventional Neurogenic Niches and Neurogenesis Modulation by Vitamins. J Stem Cell Res Ther 4: 184 doi:10.4172/2157-7633.1000184

Copyright: ( 2014 Oyarce K, et al. This is an open-access article distributed under the terms of the Creative Commons Attribution License, which permits unrestricted use, distribution, and reproduction in any medium, provided the original author and source are credited. 
Citation: Oyarce K, Nualart F (2014) Unconventional Neurogenic Niches and Neurogenesis Modulation by Vitamins. J Stem Cell Res Ther 4: 184. doi:10.4172/2157-7633.1000184

Page 2 of 11

in evaluating the results, because high or low proliferation rates can be detected. One of the pitfalls of this technique is the possibility of staining cells undergoing DNA repair. However, it remains the most commonly used method to date [33].

To assess the identity of the dividing cell and their progeny, several markers have been used in tissue samples or in vitro assays. Although there are no specific markers that make possible the indisputable identification of NSCs to date, there is a consensus regarding a group of proteins, including nestin, SOX-2 and prominin-1 (for a complete list of NSCs markers refer to [34]), known to be expressed by embryonic NSCs that virtually gives rise to all of the adult neural progenitors, and by adult NSCs isolated from neurogenic niches. Whether combinations of these markers stain different NSCs with diverse intrinsic potentials or different commitment stages of the same NSC remains to be determined. For differentiated cells, common markers include $\beta$-III tubulin and neuronal nuclei protein (NeuN) (for neurons), glial fibrillary acidic protein (GFAP; for astrocytes) and oligodendrocyte transcription factor (Olig2; for oligodendrocytes).

\section{Hypothalamus}

The hypothalamus is a small part of the diencephalon, located on either side of the third ventricle, extending from the rostral limit of the optic chiasm to the caudal limit of the mammillary bodies. It is composed of neuronal nuclei involved in several functions, such as feeding [35,36], sexual behavior [37], temperature control [38] and emotional response [39]. Lining the walls of the third ventricle, a single layer of cells is found. At the dorsal zone, the layer is composed of multi-ciliated ependymal cells, while the ventral zone is formed by specialized glial cells with long radial processes called tanycytes, which are thought to be derived from the first ones [40]. Tanycytes express vimentin, nestin and brain lipid binding protein (BLBP) [41] and can be classified in terms of their morphology, marker expression and localization into $\alpha 1$, dorsal and ventral $\alpha 2$, lateral $\beta 1$ and medial $\beta 2$ tanyctes $[42,43]$.

At the middle of the third ventricle, a transitional zone can be distinguished, harboring both ependymal cells and tanycytes, and beneath this layer, a GFAP-positive stratum of flat cells with

A

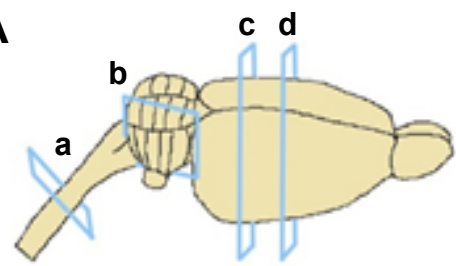

B

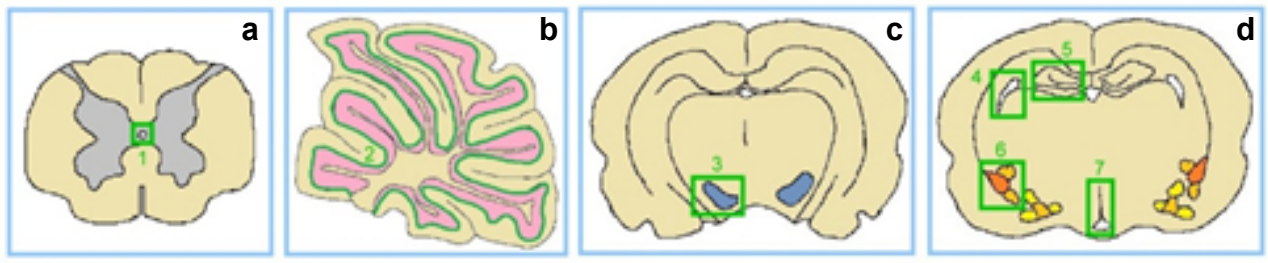

C

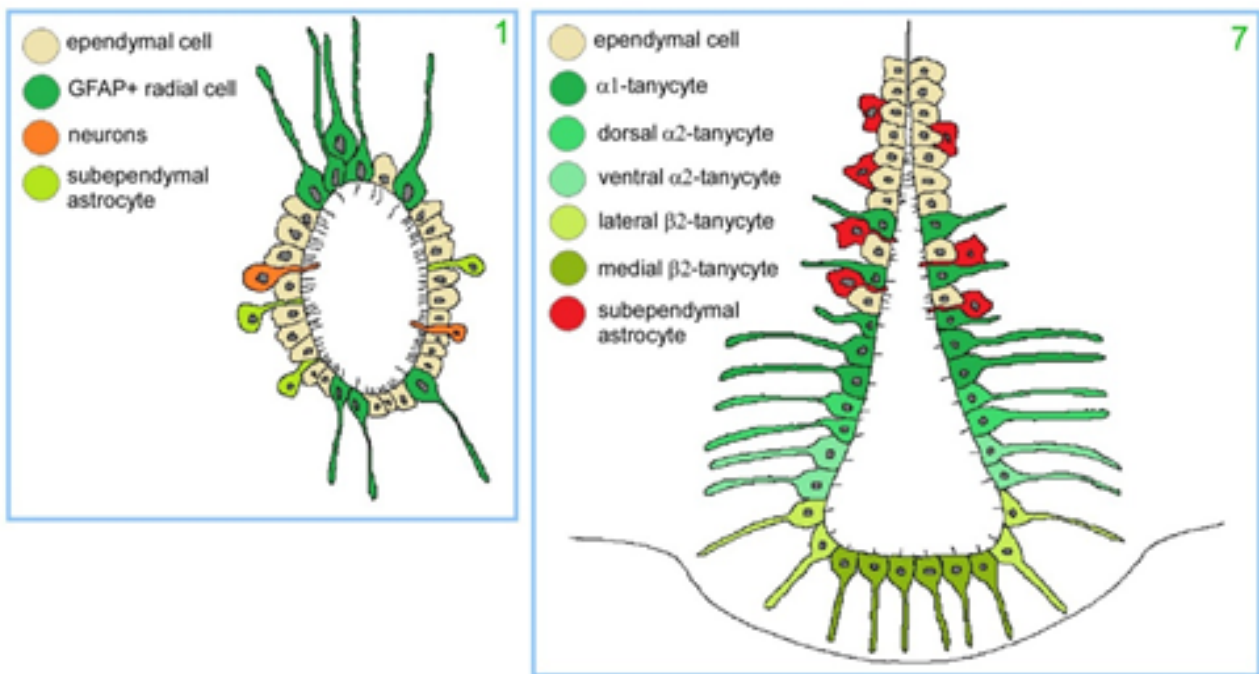

Figure 1: Classical and unconventional neurogenic niches. A: longitudinal view of a rat brain and part of the spinal cord, indicating cross sections. B: Cross sections of spinal cord (a), cerebellum (b) and rat brain (c, d) at different levels. Regions where neurogenic potential or NSC presence has been demonstrated are highlighted in green. Spinal cord central canal (1), Purkinje cell layer (2), substantia nigra (3), SVZ of the lateral ventricles (4), SGZ of the dentate gyrus (5), amygdala (6) and hypothalamus (7). C: Cellular composition of the newly described neurogenic niches: central canal (left panel) and hypothalamus (right panel). 
astrocytic characteristics is found [40]. Some of these cells contact the cerebrospinal fluid (CSF) through an apical process. Also, at this transition zone, a labyrinth system of basement membrane can be observed, a feature recognized to be typical of adult neurogenic niches [44].

One of the first articles describing proliferation within the hypothalamus showed very few BrdU- labeled cells surrounding the third ventricle after two weeks of intracerebroventricular administration of BrdU, with about $20 \%$ of these cells expressing neuronal markers [45]. However, proliferation and neuronal differentiation could be enhanced with brain-derived neurotrophic factor (BDNF) in vivo [45]. Endogenous hypothalamic proliferation can be also stimulated by ventricular infusion of basic fibroblast growth factor (bFGF) [41]. After a few days of bFGF treatment, some BrdU-positive cells are also nestin-positive with the morphology characteristic of tanycytes. After a month, these cells exhibited neuronal or glial markers near the third ventricle, suggesting differentiation into both lineages. Dissociation of hypothalamic tissue and neurosphere cultures added new evidence for the existence of hypothalamic precursor cells that could be isolated, cultured and differentiated in vitro, giving rise to neurons and glial cells [41].

Cilliary neurotrophic factor (CNTF) also increases proliferation near the third ventricle [46]. Importantly, some of the newly generated neurons expressed the oxygenic neuropeptide, neuropeptide Y (NPY), and were also activated after injection of leptin injection (a key hormone known to inhibit appetite), proving they were functionally active [46]. This time, however, the increased number of BrdU-positive cells was more predominant at the base of the third ventricle, in contrast to the widespread distribution along the third ventricle, previously noted [46].

Insulin growth factor type 1 (IGF-I) also stimulates proliferation within the hypothalamus. However, it was noted primarily at the lining of the third ventricle and the parenchymal area, specifically increasing the amount of BrdU-labeled cells at the medio-ventral portion [40], which corresponds to the transition zone between the ependymal cells and tanycytes. The nature of the BrdU-positive cells was characteristic of tanycytes and subependymal astrocytes. Eighteen days after of BrdU staining and IGF treatment, half of the proliferating cells differentiated into neuronal cells, which was more than that observed in control animals [40].

Taken together, endogenous proliferation and neurogenic potential that can be enhanced by several factors (BDNF, CNTF and IGF) was observed in the hypothalamus. In addition, both tanycytes and subependymal astrocytes were labeled by BrdU. Finally, two hypothalamic regions were noted for their proliferative capacity: the base of the third ventricle and the transitional zone.

Two more recent articles have added evidence in favor of each niche and describe hypothalamic proliferation in the absence of exogenous stimuli $[42,47]$. One study determined that the most proliferative zone corresponded to the base of the third ventricle at the median eminence $[46,47]$. These precursor cells were identified as $\beta 2$-tanycytes. The authors showed that with post-natal development, the number of new neurons in this region increased, and in vivo fatemapping analysis indicated that these new neurons were derived from $\beta 2$-tanycytes. Moreover, in response to fasting or leptin infusion, the new neurons proved to be functionally active. Alternatively, the other study used transgenic mice expressing a reporter protein under the glutamate aspartate transporter (GLAST) promoter to specifically label $\alpha$-tanycytes [42]. The number of labeled tanycytes increased over time, and new cells appeared in other regions harboring $\beta$-tanycytes, suggesting the expansion of $\alpha$-tanycytes and the generation of other types from the latter. After nine months, $44 \%$ of the reporterpositive cells were GFAP-positive, indicating glial differentiation; only approximately $2 \%$ had a neuronal phenotype. This data suggest that under normal conditions, $\alpha$-tanycytes are capable of generating glia as well as very low levels of neurons. FGF2 infusion increased the proliferation of these precursor cells, which was necessary for their endogenous proliferation in situ [42]

Although the proposal of two different hypothalamic niches might seem conflicting, different types of tanycytes may represent various stages in the life of a stem cell, with different intrinsic capacities for self-renewal, generating astrocytes or neurons, as well as different responsiveness to exogenous signals. Alternatively, the possibility of subependymal astrocytes as NSCs cannot be ruled out.

\section{Substantia Nigra}

The substantia nigra (SN) corresponds to a portion of the brain localized in the mesencephalon, deep within the brainstem, immediately dorsal to the cerebral peduncles. It harbors specialized neurons, called dopaminergic neurons, which are responsible for the regulation of corticostriatal neurotransmission, involved in motor function. This neuronal circuit has received a lot of attention because it is severely affected in Parkinson's disease (PD).

The first evidence showing the presence of precursor cells in the SN came from Gage's group [48]. They observed the presence of small, highly branched cells with round bodies that were able to incorporate BrdU and proliferate locally within the adult SN. Half of these cells were positive for the glial precursor marker, chondroitin sulfate proteoglycan (NG2), and their fate in situ was only of glial lineage, giving rise to oligodendrocytes and astrocytes. However, isolation of these cells followed by in vitro clonal analysis and differentiations assays indicated that their differentiation potential was broader, giving rise to both glial and neuronal cells [48]. Finally, after these precursor cells were grafted into the hippocampus of adult rats, they were also able to differentiate into neurons, proving that the $\mathrm{SN}$ actually contains a population of NSCs that are regionally restricted to become glia.

Although the observation of BrdU-positive cells in the SN was repeated by several other studies [49-51], the identity of these cells has become a matter of debate. Some argued that the cells were tyrosine hydroxylase (TH) -positive dopaminergic neurons [51], while others demonstrated that the BrdU-positive cells were in fact in close proximity to TH-positive neurons $[49,50]$. In an attempt to stimulate the endogenous SN precursor cells to change their default differentiation, local damage was induced or protective agents were administrated, but neither dopaminergic neuron degeneration by 1-methyl-4-phenyl-1,2,3,6-tetrahydropyridine (MPTP) or 6hydroxydopamine (6-OHDA) treatment, nor the use of growth and neurotrophic factors were able to induce neurogenesis in this brain region [52-54]. The common result was increased proliferation of precursor cells with continued differentiation towards the glial lineage.

Most recently, adult human neural precursor cells (AHNPs) have been isolated and cultured from the SN of post-mortem PD brains [55]. The authors reported that these cells grew at a slower rate and required special culture conditions to differentiate, as compared with AHNPs derived from the temporal lobe of epileptic brains. However, using 
these conditions, they succeeded in differentiating the cells into both glia and neurons (even TH-positive neurons) in vitro and in vivo, which definitely holds new promise for PD therapy development. Whether these PD AHNPs remain quiescent and less prone to differentiate due to $\mathrm{PD}$ pathogenesis or the human $\mathrm{SN}$ itself has limited potential remains unclear.

\section{Cerebellum}

The cerebellum is an encephalic structure of the hindbrain, located at the back of the brain, underlying the occipital and temporal lobes of the cerebral cortex. For a long time, this brain region has been recognized as the movement coordination center [56]. However, in the last decade, strong evidence has indicated its involvement in higher functions, such as temporary memory, cognition and learning capabilities $[57,58]$. Thus, more studies have been undertaken to define cerebellar neural plasticity.

The adult cerebellum can be easily divided into three layers consisting of different cell types, surrounding an inner core of cerebellar white matter (WM), which harbors oligodendrocytes, astrocytes and deep cerebellar neuronal nuclei [59]. The internal granular layer (IGL) is immediately above the WM and is formed by numerous granule neurons and Golgi, Lugaro and unipolar brush cells [60]. Above the IGL, lies the Purkinje cell layer, formed by the juxtaposition of the somas of Purkinje neurons and Bergmann glia. Finally, the most external sheet is called the molecular layer, because it is mostly formed by fibers and neuronal processes $[61,62]$. Unlike any other part of the brain, the cerebellar structure is fully developed at early post-natal stages. Multiple precursor expansions, cell migrations and neuronal maturation occur in this region within the first two weeks in rodents or two years in humans [63-65].

The first article describing the isolation of adult cerebellar NSCs ( $>42$ days-old) showed that some cells from the adult cerebellum could proliferate in vitro, self-renew and give rise to both glial cells and neurons although at low frequencies [66]. These newly generated neurons expressed markers associated with all of the neuronal classes found in the adult cerebellum, including parvalbumin and calbindin. Using GFP-expressing mice, the authors isolated, cultured and grafted these cerebellar precursor cells into the cerebellum of 4 day-old (P4) wild-type mice. After two weeks, the grafted cells were scattered throughout all the cerebellar layers, even in the WM tracks, and were able to differentiate into several neuronal types as well as glial cells [66]. More interestingly, the majority of the cells acquired a granular cell identity, due to their location, functional responses and marker expression. This observation is noteworthy because granular cells are derived from a particular pool of restricted progenitor cells, and they establish their final position at the IGL around P15. Therefore, the fact that adult cerebellar NSCs are capable of giving rise to granular neurons at later stages suggests a novel source for this lineage.

Although it was the first work providing evidence for the presence of adult cerebellar NSCs, the identity and location of these cells was undefined. Using P7 Math1-GFP mice, another group isolated a population of Math1-positive cells (granular cell precursors) and Math1-negative cells by FACS, and further analyzed the identity of the latter pool of cells [25]. The Math1-negative cells included cells positive for nestin and prominin-1, and in situ hybridization revealed that the prominin-1-positive cells were mostly located within the WM. Approximately $50 \%$ of the promimin-1-positive cells also expressed neuronal markers; $40 \%$ of them expressed glial markers, and just $10 \%$ were uncommitted to either of these lineages. Subsequent analysis of the population of uncommitted cells revealed that they generated neurospheres and differentiated into neurons and glia in vitro, and after transplantation into neonatal mice [25]. Although this was the first article describing the location of cells with stem cell properties within the post-natal cerebellum, at the developmental stage analyzed (P7), different progenitor cells are still present in the cerebellar WM; therefore, it is not considered an adult cerebellum at this stage.

In a subsequent study, expression of the NSC markers, SOX-1 and SOX-2, was demonstrated in the cerebellar tissue of 2 monthold mice [67]. These transcription factors, which are important for maintaining the undifferentiated state of NSCs, were only expressed by the Bergmann glia, posing the possibility that this cell type could be the adult cerebellar NSC. The idea was reinforced by the fact that Bergmann glia exhibits the same morphological and expression profile as embryonic radial glia, including long radial processes and expression of vimentin, BLBP, GLAST, S100 and GFAP [68]. Also, during early post-natal development, Bergmann glia express nestin until completion of Purkinje and granular neuronal migration, but this expression can be induced in adulthood after injury or after Purkinje cell transplantation [69]. Thus, it was suggested that the prominin-1positive cells found in the WM of P7 mice could be in fact Bergman glia progenitor cells [68]. This idea was further substantiated by analyzing SOX-1 expression during cerebellar development, which indicated that SOX1-positive cells were scattered throughout the internal cerebellum region at $\mathrm{P} 4$, and eventually, SOX-1 expression was restricted to the Bergmann glia [70]. Moreover, isolation of prominin-1-positive cells from a P7 cerebellum showed that $90 \%$ of the cells were also positive for SOX-1; these cells also grew and formed neurospheres in vitro. Taken together, these data suggest that there is a pool of cells in the adult cerebellum that is capable of proliferation and differentiation in vitro, along with the NSC phenotype exhibited by the Bergmann glia. However, no study has demonstrated proliferation and neurogenesis in the adult cerebellum under physiological or pathological circumstances in vivo. The lack of proliferative assays and fate-map analysis of the progenitors identified to date hinders the establishment of an adult cerebellar neurogenic niche.

\section{Amygdala}

The amygdala is an almond-shaped structure, located deep in the rostral portion of the medial temporal lobe. It is composed of several neuronal nuclei establishing connections with different parts of the brain, including the cortex and hypothalamus [71]. It is involved in a variety of functions primarily associated with emotional behavior, such as fear, anxiety [72,73], pleasure [74], social interaction $[75,76]$ and appetite [77]. Several studies have associated this structure in psychiatric and neurodevelopment disorders, including autism [76]. Thus, considerable attention has been dedicated to understanding amygdala plasticity.

There are very few articles describing neurogenesis in the amygdala, some of which are quite controversial. One of the first studies in squirrel monkeys showed the presence of numerous BrdU-labeled cells, which formed a continuous pathway from the rostral tip of the lateral ventricles temporal horn to the amygdala and piriform cortex after weeks of BrdU administration [78]. In this stream, immature neurons in migration were observed. However, the same authors suggested that it is likely that these proliferating cells in the amygdala came from the SVZ, demonstrating the existence of another path in addition to the RMS [78]. 
In a subsequent study of epileptic rats, induced by repeated treatment with a GABA-antagonist, severe cell death was observed in different brain regions, including the amygdala, in addition to an increase in the number of BrdU-labeled cells, which were shown to be neurons [79]. Although the authors suggested that epileptic seizures caused an increase in proliferation, BrdU incorporation due to apoptotic DNA damage was not discussed.

A more convincing article described that enrichment of the environment (defined as wider cages with multiple toys) increased proliferation in the amygdala of rodents [80]. Following intraperitoneal injection of BrdU, the authors observed few labeled cells after two weeks, and most of the BrdU-positive cells were oligodendrocytes. After a longer time period, the authors determined that an enriched environment increased the number of BrdU-positive cells and produced a larger number of new astrocytes as compared to the control environment. However, no new neurons were detected under these conditions.

Therefore, whether the amygdala indeed harbors local NSCs capable of giving rise to glia and neurons or is only a new destination site for precursors derived from the SVZ remains to be defined.

\section{Spinal Cord}

The spinal cord is a long tubular structure, located inside the backbone, extending from the foramen magnum at the base of the skull to the conus medullaris between the first and second lumbar vertebra. Its main function is to integrate proprioceptive input and motor output, through dorsal (sensitive) and ventral (motor) nerve roots that emanate from spinal segments [81]. The spinal cord is composed of two major types of tissue easily recognizable in transversal sections: the external zone (white matter), formed mainly by myelinated motor and sensory axon fibers, and the inner region (grey matter), harboring interneurons and motor neuron cell bodies [81]. A fine cylindrical space, called the central canal, containing CSF is found in the middle.

Precursor cells, some of which exhibit stem cell markers, selfrenew, and possess different proliferation rates depending on the region of isolation, have been successfully isolated and cultured from the adult spinal cord by different groups [82-84]. Clonal analysis has proven that some of these cells are multipotent. However, transplantation into the spinal cord of adult rats revealed that they remained mostly undifferentiated, with some expressing glial markers; in the hippocampus, a large amount differentiated into neurons $[82,83]$, suggesting the presence of cues that suppress neuronal differentiation in the adult spinal cord.

In situ proliferation also occurs in the adult spinal cord, increasing after injury, particularly in the white matter $[85,86]$. However, most of these cells were glial progenitors that continue to proliferate during adulthood, giving rise to astrocytes and oligodendrocytes [85]. More recent studies indicate that adult NSCs are actually located at the lining of the central canal, and can proliferate and self-renew in vitro $[87,88]$. This proposal has strengthened with the emergence of new evidence that is starting to define a niche. Moreover, FGF and EGF infusion into the fourth ventricle increased the number of BrdU-labeled cells in the central canal, with most being nestin- positive; however, subsequent generation of new neurons was not detected [87]. In addition, fate- map analysis using CreER transgenic mice with $\beta$-galactosidase expression under nestin regulatory sequences showed that the expression was limited to the central canal [88]. These cells were vimentin-, SOX-1-,
SOX-2- and prominin-1-positive, but GFAP- and Olig2-negative, indicating NSC properties. Ultrastructure analysis determined that the central canal lining was formed by different cell types classified as tanycytes, cuboidal ependymal cells and radial ependymal cells. Spinal cord neurospheres derived from these mice revealed cells from the central canal could self-renew and differentiate into both neuronal and glial lineages in vitro. In addition, after injury not compromising the central canal, the authors proved there was an increase in the number of proliferative ependymal cells that was located outside the ependymal layer, migrating towards the site of injury, and forming part of the glial scar along with reactive astrocytes after several weeks [88]. After a month, some of the recombined ependymal cells gave rise to oligodendrocytes scattered through the spinal cord, which are needed for re-myelination of damaged axons.

In a subsequent study, the heterogeneous conformation of the central canal was confirmed; however, its composition was revisited, showing that GFAP-positive cells contacting the lumen were especially abundant at the medial dorsal region, where they also exhibited long radial processes, and some were BLBP-positive (presumably tanycytes in the previous work) [89]. The authors also observed immature neuronal cells located in the subependymal layer that had a process that protruded into the lumen. The neurosphere generation capacity of the central canal cells was confirmed, but more importantly, the identity of the putative stem cell was determined. The authors showed that most of the neurospheres originated from GFAP-positive cells, most likely the ones possessing radial processes, but without discarding subependymal astrocytes.

This newly described niche at the central canal resembles that described in the hypothalamus, where not just one type of cell lining the ventricle shows NSC properties. Although few papers have described the presence of newly generated immature neurons in the adult spinal cord in physiological conditions [90] or after injury without glial scar formation [91], the majority of studies report the absence of neuronal generation in vivo. Thus, further analysis is needed to confirm the positive results.

\section{Vitamins and NSC Modulation}

\section{Vitamin A}

Vitamin A, also known as retinol, is a liposoluble vitamin obtained from the diet. When oxidized by two sequential enzymatic steps, it becomes the active derivative, retinoic acid (RA), a non-steroid hormone, regulating patterning and differentiation in vertebrate tissues, especially in the central nervous system (CNS) [92-97]. However, at higher concentrations, RA is teratogenic, highlighting the importance of regulating its levels [98-101]. Retinol travels through blood stream carried by the retinol binding protein (RBP) and enters target cells through its interaction with the RBP receptor, STRA6 [102]. Inside the cell, it interacts with cellular retinol-binding protein (CBRP) that allows proximity with the enzymes responsible for its conversion to RA: retinol and retinal dehydrogenases (RDH and RALDH, respectively) [97,103]. RA can impact cells in a paracrine or autocrine fashion through its interaction with RA receptors (RARs), which are ligand-activated transcription factors that bind retinoid $\mathrm{X}$ receptors (RXRs), translocate to the nucleus, and interact with RA response elements (RARE) to regulate gene expression $[93,97,104]$. Some RA target genes are known patterning and differentiation factors, such as sonic hedgehog (Shh), bone morphogenic protein (BMP) and Wnt $[105,106]$. 
In the CNS at embryonic stages, RA is secreted by the meninges and taken up by the NSC radial glia, allowing neurogenesis and cortical expansion [107]. In the adult brain, RA increases neuronal differentiation of NSCs in vitro $[108,109]$. Mice expressing the LacZ transgene under a promoter downstream of RARE sequences have permitted the precise localization of RA signaling [110,111], making it possible to analyze the effects of RA modulation on adult neurogenesis. However, the responsiveness to RA is influenced by the presence of the proteins needed for the uptake and synthesis of RA, the expression of the RAR/RXR receptors, as well as the RA gradient coming from the meninges or other cell sources.

Of all of the niches characterized to date, the effect of RA on NSC proliferation and neurogenesis has only been determined in the SVZ and SGZ [109,112]. Nevertheless, the presence of many of the RA signaling components has been detected in the unconventional neurogenic niches $[106,113,114]$.

Using RARE-LacZ mice, RA signaling was demonstrated in the adult SVZ; the RA-responsive cells were nestin-, SOX-1-, SOX-2- and GFAP-positive with low proliferation rates, indicating that they are NSCs [115]. These NSCs expressed multiple RA receptors in culture, and after RA treatment, the number of new, immature neurons increased in vitro [109]. In addition, RA and retinol stimulated proliferation and neurogenesis in SVZ explants, an effect that was ablated by RALDH inhibitors, indicating that the SVZ expresses the enzymes necessary for RA synthesis [109]. This suggests that RA, which is likely synthesized from the niche itself, stimulates NSCs to generate new neurons. Moreover, inhibition of RA signaling by the expression of the dominant-negative RA receptor indicates that RA not only stimulates neurogenesis in the SVZ, but it is also crucial for the correct differentiation and migration of newly generated neurons along the RMS [109].

In the adult hippocampus, RA plays a role in modulating both neuronal plasticity, and neurogenesis [112,116]. It is known that retinol deficiency leads to a loss of long-term synaptic plasticity [117] and impairment of spatial memory [118]. It also diminishes hippocampus proliferation and the number of newly generated neurons expressing early neuronal markers without altering astrocyte generation $[112,119]$. These effects, however, are compensated when RA is directly administrated to mice [119], without affecting animals consuming a normal diet. However, the presence of different components of RA signaling in the dentate gyrus region has only recently been determined, which established that the meninges are main source of $\mathrm{RA}$, and its diffusion creates a gradient across the dentate gyrus blades [120]. However, the exact cell that is receiving and responding to RA remains undetermined. Similarly, in the hypothalamus, populations of tanycytes (most likely $\beta 1$--type due to their location) express the necessary components for the entrance, synthesis and signaling of RA; they also are capable of releasing RA [121,122]. Moreover, hypothalamic neurons surrounding the third ventricle are known to express RA receptors, making them responsive to the RA signal released by tanycytes $[122,123]$. However, further studies to determine the particular cell type that is transcriptionally regulated by RA signaling and evaluate if RA modulates hypothalamic neurogenesis in vivo are required.

\section{Vitamin C}

Vitamin C is a water soluble vitamin that alternates between two main chemical states: the oxidized form, dehydroascorbic acid (DHA), and the reduced form, ascorbic acid (AA), which is predominant at physiological $\mathrm{pH}$ [124]. Although most mammals can synthesize vitamin $C$ from glucose, guinea pigs, humans and primates are unable to do so because they lack the enzyme that catalyzes the last step of its biosynthesis [125]. For this reason, vitamin C must be obtained from the diet.

AA is highly concentrated in the CNS, where it participates in a wide range of functions crucial for normal development and maintenance $[124,126]$. It acts as a co-factor in several enzymatic reactions, including collagen [127], catecholamine [128-130], carnitine [131], cholesterol, and hormonal peptides synthesis [132]; it also modulates dopaminergic and glutamatergic synapsis formation $[133,134]$, promotes myelination [135] and has a powerful antioxidant capacity, exerting a protective role during oxidative stress $[124,126,136$ 139]. Thus, vitamin $C$ deficiency causes severe physiological disorders, including neurological alterations [140-142].

In the last decade, several studies also have shown that AA stimulates differentiation of different cell types, including NSCs in vitro [143-151], increasing the number of neuronal and glial cells in culture and up-regulating many genes involved in neuronal differentiation, maturation and plasticity $[152,153]$. However, unlike the known RA signaling pathway, the AA signaling cascade that mediates these phenomena has remained mostly obscure. It is known that AA enters cells through the sodium-dependent vitamin $C$ transporters, SVCT1 and SVCT2, which are predicted to have 12 transmembrane domains with phosphorylation and glycosylation sites that regulate its subcellular localization [154-158]. Of the two transporters, only SVCT2 is present in brain tissue, specifically within hippocampal [159], cortical $[160,161]$ and cerebellar neurons [162], as well as the choroid plexus [163] and hypothalamic tanycytes [164]. In addition, AA uptake by SVCT2 can be regulated at the transcriptional and posttranslational levels, as well as by the presence of short isoforms acting as dominant-negative regulators [149,150,154,165-167], suggesting a tight regulation of AA levels.

In the SGZ niche, AA deficiency in guinea pigs reduces the number of neurons in the hippocampal region by $30 \%$, altering spatial memory [168]. However, the data does not distinguish between increased cell death, reduced progenitor proliferation or decreased neurogenesis from SGZ NSCs. In a later work by the same authors, pre-natal AA deficiency altered hippocampal volume and impaired the migration of newly formed cells, without changing the expression of neuronal markers [169].

More recently, SVCT2 expression has been observed in the transient progenitor cells from the adult SVZ [170]. Moreover, when these precursor cells were isolated, they formed floating neurospheres that expressed SVCT2 in culture, incorporated AA, and had increased expression of neuronal markers after AA treatment, indicating that these progenitor cells are responsive to $\mathrm{AA}$, which stimulates neurogenesis [170].

Although AA induced neuronal differentiation in vitro and its transporter is present in the adult SVZ niche, more evidence is needed to determine if AA is required for adult neurogenesis. Also, the effect of AA on other niches remains to be determined.

\section{Vitamin D3}

Vitamin D3, or cholecalciferol, is a liposoluble secosteroid that belongs to the vitamin D group. Although it can be obtained from the 
diet, it is mostly synthesized in the skin after exposure to sunlight from the precursor, 7-dehydrocholesterol [171]. Vitamin D3 travels through the blood stream attached to the vitamin D binding protein (DBP), and in the liver, it is converted to the major circulating form, $25(\mathrm{OH})$ $\mathrm{D}_{3}$. In the kidney, it is converted into the active form, 1,25 $(\mathrm{OH})_{2} \mathrm{D} 3$ $[172,173]$, which will be subsequently referred to as simply vitamin D. In addition to bone calcium mobilization [174] and immune response regulation [175], the presence of vitamin D metabolites in the CSF and expression of the vitamin D receptor (VDR) in embryonic and adult brain tissues [176] suggests that it is also important for normal brain function. Moreover, vitamin D deficiency alters brain development, with thinner brain cortices and larger ventricle volume being observed in newborn pups [177]; it also increases proliferation and reduces apoptosis [178]. Ultimately, vitamin D deficiency recapitulates certain symptoms of neurological and psychiatric disorders [29,179-182].

As with retinol, vitamin D executes its multiple functions through binding VDR, a ligand-activated transcription factor, triggering the expression of target genes that possess vitamin D response elements (VDREs) [183,184], including those associated with proliferation, growth and differentiation [185]. Interestingly, VDR expression has been observed within the classical and unconventional neurogenic niches, including the SVZ, hippocampus, cerebellum and hypothalamus [176,186]. Also, the enzyme responsible for vitamin D synthesis is found in the $\mathrm{SN}$ and hypothalamic paraventricular nuclei [176]. However, the few articles that have described a potential effect of vitamin D on adult neurogenesis have focused on the SVZ and SGZ [185]. The first study described the presence of VDR in neonatal SVZ precursor cells in culture, and demonstrated that the number of neurospheres increased by $40 \%$ in animals consuming a vitamin D deficient diet. Conversely, the addition of vitamin D to NSC cultures diminished the number of neurospheres in control animals, without affecting deficient ones [185]. In another study that used 1 $\alpha$-hydroxylase knockout mice, which are unable to synthesize vitamin $\mathrm{D}$, the authors showed that after two months of life, the number of proliferative cells in the hippocampus was increased, compared to wild-type animals; however, apoptosis increased and most of the newly generated cells died over time, indicating a reduced survival [187]. These effects were shown to be ameliorated with vitamin D administration. However, the proportion of cells that were double- labeled for BrdU and neuronal or glial markers remained the same between the control and vitamin $\mathrm{D}$ deficient animals, suggesting vitamin $\mathrm{D}$ deficiency does not alter the differentiation of SGZ progenitors [187]. It would be interesting to determine the effects of vitamin D deficiency on the proliferation and survival of cells within unconventional niches, and analyze if regulating the timing of deficiency and repletion can compensate the long-term effects on apoptosis, leading to a net increase in neurogenesis.

\section{Conclusions}

Adult neurogenesis in both the SVZ and SGZ is now unarguably recognized to take place in rodent, primate and even human brains, and a lot of effort has been made to understand the signals and the molecular mechanisms underlying its tight regulation. The dream of being able of modulate the neurogenic process and migration of new neurons persists and grows with new evidence showing neurogenic potential in other brain regions and different routes of migration from the classical niches. In this review, we have revisited what it is known about the potential of the unconventional neurogenic niches to generate neurons, giving details about its cellular composition and the evidence in favor of the presence of adult NSCs that can be regulated by several factors in vitro and in vivo. Although these newly described niches have been met with skepticism by the scientific community, it is worth noting that there was also major disbelief in the existence of neurogenic capacity in the adult brain. Clearly, more in vivo and in situ data are needed to determine if new neuronal generation occurs in these unconventional neurogenic niches under physiological circumstances. However, even if they lack the endogenous capacity to generate neurons in vivo, they may still contain NSCs that can be activated in a definite time or in response to specific stimuli, which is extremely valuable in terms of understanding the regenerative capacity of the brain during pathological conditions. For the sake of ending a semantics controversy, perhaps it would be better if we refer to these regions as "NSC harboring", instead of "neurogenic" niches.

\section{Acknowledgments}

This work was funded by a FONDECYT grant 1140477 and CONICYT-PIA ECM-12.

\section{References}

1. Braun SM, Jessberger S (2014) Adult neurogenesis and its role in neuropsychiatric disease, brain repair and normal brain function. Neuropathol Appl Neurobiol 40(1): 3-12.[Pubmed]

2. Ming GL, Song $H$ (2005) Adult neurogenesis in the mammalian central nervous system. Annu Rev Neurosci 28: 223-250.[Pubmed]

3. Zhao C, Deng W, Gage FH (2008) Mechanisms and functional implications of adult neurogenesis. Cell 132(4): 645-660.[Pubmed]

4. Abrous DN, Koehl M, Le Moal M (2005) Adult neurogenesis: from precursors to network and physiology. Physiol Rev 85(2): 523-569.[Pubmed]

5. Lim DA, Tramontin AD, Trevejo JM, Herrera DG, García-Verdugo JM et al. (2000) Noggin antagonizes BMP signaling to create a niche for adult neurogenesis. Neuron 28(3): 713-726.[Pubmed]

6. Ma DK, Ming GL, Song H (2005) Glial influences on neural stem cel development: cellular niches for adult neurogenesis. Curr Opin Neurobio 15(5): 514-520.[Pubmed]

7. Song $\mathrm{H}$, Stevens CF, Gage FH (2002) Astroglia induce neurogenesis from adult neural stem cells. Nature 417(6884): 39-44.[Pubmed]

8. Alvarez-Buylla A, Garcia-Verdugo JM (2002) Neurogenesis in adult subventricular zone. J Neurosci 22(3): 629-634.[Pubmed]

9. Conover JC, Notti RQ (2008) The neural stem cell niche. Cell Tissue Res 331(1): 211-224.[Pubmed]

10. Doetsch F, Caillé I, Lim DA, García-Verdugo JM, Alvarez-Buylla A (1999) Subventricular zone astrocytes are neural stem cells in the adult mammalian brain. Cell 97(6): 703-716.[Pubmed]

11. Doetsch F, García-Verdugo JM, Alvarez-Buylla A (1997) Cellular composition and three-dimensional organization of the subventricular germinal zone in the adult mammalian brain. J Neurosci 17(13): 5046-5061.[Pubmed]

12. Doetsch F, García-Verdugo JM, Alvarez-Buylla A (1999) Regeneration of a germinal layer in the adult mammalian brain. Proc Natl Acad Sci U S A 96(20) 11619-11624.[Pubmed]

13. Ihrie RA, Alvarez-Buylla A (2008) Cells in the astroglial lineage are neural stem cells. Cell Tissue Res 331(1): 179-191.[Pubmed]

14. Mu Y, Lee SW, Gage FH (2010) Signaling in adult neurogenesis. Curr Opin Neurobiol 20(4): 416-423.[Pubmed]

15. Pencea V, Bingaman KD, Freedman LJ, Luskin MB (2001) Neurogenesis in the subventricular zone and rostral migratory stream of the neonatal and adult primate forebrain. Exp Neurol 172(1): 1-16.[Pubmed]

16. Aimone JB, Deng W, Gage FH (2010) Adult neurogenesis: integrating theories and separating functions. Trends Cogn Sci 14(7): 325-337.[Pubmed]

17. Seri B, García-Verdugo JM, Collado-Morente L, McEwen BS, Alvarez-Buylla A (2004) Cell types, lineage, and architecture of the germinal zone in the adult dentate gyrus. J Comp Neurol 478(4): 359-378.[Pubmed]

18. Seri B, García-Verdugo JM, McEwen BS, Alvarez-Buylla A (2001) Astrocytes give rise to new neurons in the adult mammalian hippocampus. $J$ Neurosci 21(18): 7153-7160.[Pubmed] 
Citation: Oyarce K, Nualart F (2014) Unconventional Neurogenic Niches and Neurogenesis Modulation by Vitamins. J Stem Cell Res Ther 4: 184. doi:10.4172/2157-7633.1000184

Page 8 of 11

19. Chazal G, Durbec P, Jankovski A, Rougon G, Cremer H (2000) Consequences of neural cell adhesion molecule deficiency on cell migration in the rostral migratory stream of the mouse. J Neurosci 20(4): 1446-1457.[Pubmed]

20. Lois C, García-Verdugo JM, Alvarez-Buylla A (1996) Chain migration of neuronal precursors. Science 271(5251): 978-981.[Pubmed]

21. Mason HA, Ito S, Corfas G (2001) Extracellular signals that regulate the tangential migration of olfactory bulb neuronal precursors: inducers, inhibitors, and repellents. J Neurosci 21(19): 7654-7663.[Pubmed]

22. Murase S, Horwitz AF (2002) Deleted in colorectal carcinoma and differentially expressed integrins mediate the directional migration of neural precursors in the rostral migratory stream. J Neurosci 22(9): 3568-3579.[Pubmed]

23. Cheng MF (2013) Hypothalamic neurogenesis in the adult brain. Front Neuroendocrinol 34(3): 167-178.[Pubmed]

24. Fowler CD, Liu Y, Wang $Z$ (2008) Estrogen and adult neurogenesis in the amygdala and hypothalamus. Brain Res Rev 57(2): 342-351.[Pubmed]

25. Lee A, Kessler JD, Read TA, Kaiser C, Corbeil D, et al. (2005) Isolation of neural stem cells from the postnatal cerebellum. Nat Neurosci 8(6): 723-729. [Pubmed]

26. Obermair FJ, Schröter A, Thallmair M (2008) Endogenous neural progenitor cells as therapeutic target after spinal cord injury. Physiology (Bethesda) 23: 296-304.[Pubmed]

27. van den Berge SA, van Strien ME, Hol EM (2013) Resident adult neural stem cells in Parkinson's disease--the brain's own repair system? Eur J Pharmacol 719(1-3): 117-127.[Pubmed]

28. Blaise SA, Nédélec E, Schroeder H, Alberto JM, Bossenmeyer-Pourié C, et al. (2007) Gestational vitamin B deficiency leads to homocysteine-associated brain apoptosis and alters neurobehavioral development in rats. Am J Pathol 170(2): 667-679.[Pubmed]

29. Eyles DW, Feron F, Cui X, Kesby JP, Harms LH, et al. (2009) Developmental vitamin $\mathrm{D}$ deficiency causes abnormal brain development. Psychoneuroendocrinology 34 Suppl 1: S247-S257.[Pubmed]

30. Levenson CW, Figueirôa SM (2008) Gestational vitamin D deficiency: longterm effects on the brain. Nutr Rev 66(12): 726-729.[Pubmed]

31. Ramakrishna T (1999) Vitamins and brain development. Physiol Res 48(3): 175-187.[Pubmed]

32. Sable P, Dangat K, Kale A, Joshi S (2011) Altered brain neurotrophins at birth: consequence of imbalance in maternal folic acid and vitamin $B_{12}$, metabolism. Neuroscience 190: 127-134.[Pubmed]

33. Taupin $P$ (2007) BrdU immunohistochemistry for studying adult neurogenesis: paradigms, pitfalls, limitations, and validation. Brain Res Rev 53(1): 198-214. [Pubmed]

34. Basak O, Taylor $\vee(2009)$ Stem cells of the adult mammalian brain and their niche. Cell Mol Life Sci 66(6): 1057-1072.[Pubmed]

35. Nakazato M, Murakami N, Date Y, Kojima M, Matsuo H, et al. (2001) A role for ghrelin in the central regulation of feeding. Nature 409(6817): 194-198. [Pubmed]

36. Sakurai T, Amemiya A, Ishii M, Matsuzaki I, Chemelli RM, et al. (1998) Orexins and orexin receptors: a family of hypothalamic neuropeptides and $G$ proteincoupled receptors that regulate feeding behavior. Cell 92(4): 573-585.[Pubmed]

37. Kippin TE, Sotiropoulos V, Badih J, Pfaus JG (2004) Opposing roles of the nucleus accumbens and anterior lateral hypothalamic area in the control of sexual behaviour in the male rat. Eur J Neurosci 19(3): 698-704.[Pubmed]

38. Boulant JA (2000) Role of the preoptic-anterior hypothalamus in thermoregulation and fever. Clin Infect Dis 31 Suppl 5: S157-161.[Pubmed]

39. Simonov PV (1997) Brain mechanisms of emotions. Neurosci Behav Physiol 27(4): 405-413.[Pubmed]

40. Pérez-Martín M, Cifuentes M, Grondona JM, López-Avalos MD, Gómez-Pinedo U, et al. (2010) IGF-I stimulates neurogenesis in the hypothalamus of adult rats. Eur J Neurosci 31(9): 1533-1548.[Pubmed]

41. Xu Y, Tamamaki N, Noda T, Kimura K, Itokazu Y, et al. (2005) Neurogenesis in the ependymal layer of the adult rat 3rd ventricle. Exp Neurol 192(2): 251-264. [Pubmed]

42. Robins SC, Stewart I, McNay DE, Taylor V, Giachino C, et al. (2013) Ît-
Tanycytes of the adult hypothalamic third ventricle include distinct populations of FGF-responsive neural progenitors. Nat Commun 4: 2049.[Pubmed]

43. Rodríguez EM, Blázquez JL, Pastor FE, Peláez B, Peña P, et al. (2005) Hypothalamic tanycytes: a key component of brain-endocrine interaction. Int Rev Cytol 247: 89-164.[Pubmed]

44. Adorjan I, Kalman M (2009) Distribution of beta-dystroglycan immunopositive globules in the subventricular zone of rat brain. Glia 57(6): 657-666.[Pubmed]

45. Pencea V, Bingaman KD, Wiegand SJ, Luskin MB (2001) Infusion of brainderived neurotrophic factor into the lateral ventricle of the adult rat leads to new neurons in the parenchyma of the striatum, septum, thalamus, and hypothalamus. J Neurosci 21(17): 6706-6717.[Pubmed]

46. Kokoeva MV, Yin H, Flier JS (2005) Neurogenesis in the hypothalamus of adult mice: potential role in energy balance. Science 310(5748): 679-683.[Pubmed]

47. Lee DA, Bedont JL, Pak T, Wang H, Song J, et al. (2012) Tanycytes of the hypothalamic median eminence form a diet-responsive neurogenic niche. Nat Neurosci 15(5): 700-702.[Pubmed]

48. Lie DC, Dziewczapolski G, Willhoite AR, Kaspar BK, Shults CW, et al. (2002) The adult substantia nigra contains progenitor cells with neurogenic potential. Neurosci 22(15): 6639-6649.[Pubmed]

49. Frielingsdorf $H$, Schwarz K, Brundin P, Mohapel $P$ (2004) No evidence for new dopaminergic neurons in the adult mammalian substantia nigra. Proc Natl Acad Sci U S A 101(27): 10177-10182.[Pubmed]

50. Mohapel $P$, Frielingsdorf H, Häggblad J, Zachrisson O, Brundin P (2005) Platelet-derived growth factor (PDGF-BB) and brain-derived neurotrophic factor (BDNF) induce striatal neurogenesis in adult rats with 6-hydroxydopamine lesions. Neuroscience 132(3): 767-776.[Pubmed]

51. Zhao M, Momma S, Delfani K, Carlen M, Cassidy RM, et al. (2003) Evidence for neurogenesis in the adult mammalian substantia nigra. Proc Natl Acad Sci U S A 100(13): 7925-7930.[Pubmed]

52. Chen Y, Ai Y, Slevin JR, Maley BE, Gash DM (2005) Progenitor proliferation in the adult hippocampus and substantia nigra induced by glial cell line-derived neurotrophic factor. Exp Neurol 196(1): 87-95.[Pubmed]

53. Mao L, Lau YS, Petroske E, Wang JQ (2001) Profound astrogenesis in the striatum of adult mice following nigrostriatal dopaminergic lesion by repeated MPTP administration. Brain Res Dev Brain Res 131(1-2): 57-65.[Pubmed]

54. Peng J, Xie L, Jin K, Greenberg DA, Andersen JK (2008) Fibroblast growth factor 2 enhances striatal and nigral neurogenesis in the acute 1-methyl-4phenyl-1,2,3,6-tetrahydropyridine model of Parkinson's disease. Neuroscience 153(3): 664-670.[Pubmed]

55. Wang S, Okun MS, Suslov O, Zheng T, McFarland NR, et al. (2012) Neurogenic potential of progenitor cells isolated from postmortem human Parkinsonian brains. Brain Res 1464: 61-72.[Pubmed]

56. Manto M, Bower JM, Conforto AB, Delgado-García JM, da Guarda SN, et al (2012) Consensus paper: roles of the cerebellum in motor control--the diversity of ideas on cerebellar involvement in movement. Cerebellum 11(2): 457-487. [Pubmed]

57. Allen G, Buxton RB, Wong EC, Courchesne E (1997) Attentional activation of the cerebellum independent of motor involvement. Science 275(5308): 19401943.[Pubmed]

58. Glickstein M, Doron K (2008) Cerebellum: connections and functions. Cerebellum 7(4): 589-594.[Pubmed]

59. Ghandour MS, Vincendon G, Gombos G (1980) Astrocyte and oligodendrocyte distribution in adult rat cerebellum: an immunohistological study. J Neurocyto 9(5): 637-646.[Pubmed]

60. Altman J (1972) Postnatal development of the cerebellar cortex in the rat. 3 Maturation of the components of the granular layer. J Comp Neurol 145(4): 465-513.[Pubmed]

61. Altman J (1972) Postnatal development of the cerebellar cortex in the rat. II Phases in the maturation of Purkinje cells and of the molecular layer. $\mathrm{J} \mathrm{Comp}$ Neurol 145(4): 399-463.[Pubmed]

62. Altman J (1972) Postnatal development of the cerebellar cortex in the rat. I. The external germinal layer and the transitional molecular layer. J Comp Neurol 145(3): 353-397.[Pubmed]

63. Chédotal A (2010) Should I stay or should I go? Becoming a granule cell. Trends Neurosci 33(4): 163-172.[Pubmed] 
Citation: Oyarce K, Nualart F (2014) Unconventional Neurogenic Niches and Neurogenesis Modulation by Vitamins. J Stem Cell Res Ther 4: 184. doi:10.4172/2157-7633.1000184

64. Englund C, Kowalczyk T, Daza RA, Dagan A, Lau C, et al. (2006) Unipolar brush cells of the cerebellum are produced in the rhombic lip and migrate through developing white matter. J Neurosci 26(36): 9184-9195.[Pubmed]

65. Zhang L, Goldman JE (1996) Developmental fates and migratory pathways of dividing progenitors in the postnatal rat cerebellum. J Comp Neurol 370(4): 536-550.[Pubmed]

66. Klein C, Butt SJ, Machold RP, Johnson JE, Fishell G (2005) Cerebellum- and forebrain-derived stem cells possess intrinsic regional character. Development 132(20): 4497-4508.[Pubmed]

67. Sottile V, Li M, Scotting PJ (2006) Stem cell marker expression in the Bergmann glia population of the adult mouse brain. Brain Res 1099(1): 8-17.[Pubmed]

68. Alcock J, Scotting P, Sottile V (2007) Bergmann glia as putative stem cells of the mature cerebellum. Med Hypotheses 69(2): 341-345.[Pubmed]

69. Sotelo C, Alvarado-Mallart RM, Frain M, Vernet M (1994) Molecular plasticity of adult Bergmann fibers is associated with radial migration of grafted Purkinje cells. J Neurosci 14: 124-133.[Pubmed]

70. Alcock J, Sottile V (2009) Dynamic distribution and stem cell characteristics of Sox1-expressing cells in the cerebellar cortex. Cell Res 19(12): 1324-1333. [Pubmed]

71. Ehrlich I, Humeau Y, Grenier F, Ciocchi S, Herry C, et al. (2009) Amygdala inhibitory circuits and the control of fear memory. Neuron 62(6): 757-771. [Pubmed]

72. Davis M (1992) The role of the amygdala in fear and anxiety. Annu Rev Neurosci 15: 353-375.[Pubmed]

73. Davis M, Rainnie D, Cassell M (1994) Neurotransmission in the rat amygdala related to fear and anxiety. Trends Neurosci 17(5): 208-214.[Pubmed]

74. Salamon E, Esch T, Stefano GB (2005) Role of amygdala in mediating sexua and emotional behavior via coupled nitric oxide release. Acta Pharmacol Sin 26(4): 389-395.[Pubmed]

75. Amaral DG (2003) The amygdala, social behavior, and danger detection. Ann N Y Acad Sci 1000: 337-347.[Pubmed]

76. Amaral DG, Bauman MD, Schumann CM (2003) The amygdala and autism: implications from non-human primate studies. Genes Brain Behav 2(5): 295302.[Pubmed]

77. Johnson AK, de Olmos J, Pastuskovas CV, Zardetto-Smith AM, Vivas L (1999) The extended amygdala and salt appetite. Ann N Y Acad Sci 877: 258-280. [Pubmed]

78. Bernier PJ, Bedard A, Vinet J, Levesque M, Parent A (2002) Newly generated neurons in the amygdala and adjoining cortex of adult primates. Proc Natl Acad Sci U S A 99(17): 11464-11469.[Pubmed]

79. Park JH, Cho H, Kim H, Kim K (2006) Repeated brief epileptic seizures by pentylenetetrazole cause neurodegeneration and promote neurogenesis in discrete brain regions of freely moving adult rats. Neuroscience 140(2): 673684.[Pubmed]

80. Okuda H, Tatsumi K, Makinodan M, Yamauchi T, Kishimoto T, et al. (2009) Environmental enrichment stimulates progenitor cell proliferation in the amygdala. J Neurosci Res 87(16): 3546-3553.[Pubmed]

81. Marcus E and Jacobson S (2003) Spinal Cord: Structure and Function. Integrated Neuroscience 153-179.

82. Shihabuddin LS, Horner PJ, Ray J, Gage FH (2000) Adult spinal cord stem cells generate neurons after transplantation in the adult dentate gyrus. J Neurosci 20(23): 8727-8735.[Pubmed]

83. Shihabuddin LS, Ray J, Gage FH (1997) FGF-2 is sufficient to isolate progenitors found in the adult mammalian spinal cord. Exp Neurol 148(2): 577 586.[Pubmed]

84. Weiss S, Dunne C, Hewson J, Wohl C, Wheatley M, et al. (1996) Multipotent CNS stem cells are present in the adult mammalian spinal cord and ventricular neuroaxis. J Neurosci 16(23): 7599-7609.[Pubmed]

85. Horner PJ, Power AE, Kempermann G, Kuhn HG, Palmer TD, et al. (2000) Proliferation and differentiation of progenitor cells throughout the intact adult rat spinal cord. J Neurosci 20(6): 2218-2228.[Pubmed]

86. Yamamoto S, Yamamoto N, Kitamura T, Nakamura K, Nakafuku M (2001) Proliferation of parenchymal neural progenitors in response to injury in the adult rat spinal cord. Exp Neurol 172(1): 115-127.[Pubmed]
87. Martens DJ, Seaberg RM, van der Kooy D (2002) In vivo infusions of exogenous growth factors into the fourth ventricle of the adult mouse brain increase the proliferation of neural progenitors around the fourth ventricle and the central canal of the spinal cord. Eur J Neurosci 16(6): 1045-1057.[Pubmed]

88. Meletis K, Barnabé-Heider F, Carlén M, Evergren E, Tomilin N, et al. (2008) Spinal cord injury reveals multilineage differentiation of ependymal cells. PLoS Biol 6(7): e182.[Pubmed]

89. Sabourin JC, Ackema KB, Ohayon D, Guichet PO, Perrin FE, et al. (2009) A mesenchymal-like ZEB1(+) niche harbors dorsal radial glial fibrillary acidic protein-positive stem cells in the spinal cord. Stem Cells 27(11): 2722-2733. [Pubmed]

90. Shechter R, Ziv Y, Schwartz M (2007) New GABAergic interneurons supported by myelin-specific $T$ cells are formed in intact adult spinal cord. Stem Cells 25(9): 2277-2282.[Pubmed]

91. Vessal M, Aycock A, Garton MT, Ciferri M, Darian-Smith C (2007) Adult neurogenesis in primate and rodent spinal cord: comparing a cervical dorsal rhizotomy with a dorsal column transection. Eur J Neurosci 26(10): 2777-2794 [Pubmed]

92. Campo-Paysaa F, Marlétaz F, Laudet V, Schubert M (2008) Retinoic acid signaling in development: tissue-specific functions and evolutionary origins. Genesis 46(11): 640-656.[Pubmed]

93. De Luca LM (1991) Retinoids and their receptors in differentiation embryogenesis, and neoplasia. FASEB J 5(14): 2924-2933.[Pubmed]

94. Maden M (2002) Retinoid signalling in the development of the central nervous system. Nat Rev Neurosci 3(11): 843-853.[Pubmed]

95. Marlétaz F, Holland LZ, Laudet V, Schubert M (2006) Retinoic acid signaling and the evolution of chordates. Int J Biol Sci 2(2): 38-47.[Pubmed]

96. McCaffery $P$, Dräger UC (2000) Regulation of retinoic acid signaling in the embryonic nervous system: a master differentiation factor. Cytokine Growth Factor Rev 11(3): 233-249.[Pubmed]

97. Ross SA, McCaffery PJ, Drager UC, De Luca LM (2000) Retinoids in embryona development. Physiol Rev 80(3): 1021-1054.[Pubmed]

98. D'Aniello E, Rydeen AB, Anderson JL, Mandal A, Waxman JS (2013) Depletion of retinoic acid receptors initiates a novel positive feedback mechanism that promotes teratogenic increases in retinoic acid. PLoS Genet 9(8): e1003689. [Pubmed]

99. Lammer EJ, Chen DT, Hoar RM, Agnish ND, Benke PJ, et al. (1985) Retinoic acid embryopathy. N Engl J Med 313(14): 837-841.[Pubmed]

100. Lee LM, Leung CY, Tang WW, Choi HL, Leung YC, et al. (2012) A paradoxical teratogenic mechanism for retinoic acid. Proc Natl Acad Sci U S A 109(34): 13668-13673.[Pubmed]

101.Rothman KJ, Moore LL, Singer MR, Nguyen US, Mannino S, et al. (1995) Teratogenicity of high vitamin A intake. N Engl J Med 333(21): 1369-1373. [Pubmed]

102. Kawaguchi R, Yu J, Honda J, Hu J, Whitelegge J, et al. (2007) A membrane receptor for retinol binding protein mediates cellular uptake of vitamin A Science 315(5813): 820-825.[Pubmed]

103. Napoli JL (2012) Physiological insights into all-trans-retinoic acid biosynthesis Biochim Biophys Acta 1821(1): 152-167.[Pubmed]

104. Chambon $P$ (1996) A decade of molecular biology of retinoic acid receptors. FASEB J 10(9): 940-954.[Pubmed]

105. Balmer JE, Blomhoff R (2002) Gene expression regulation by retinoic acid. J Lipid Res 43(11): 1773-1808.[Pubmed]

106. Lane MA, Bailey SJ (2005) Role of retinoid signalling in the adult brain. Prog Neurobiol 75(4): 275-293.[Pubmed]

107. Siegenthaler JA, Ashique AM, Zarbalis K, Patterson KP, Hecht JH, et al (2009) Retinoic acid from the meninges regulates cortical neuron generation. Cell 139(3): 597-609.[Pubmed]

108. Takahashi J, Palmer TD, Gage FH (1999) Retinoic acid and neurotrophins collaborate to regulate neurogenesis in adult-derived neural stem cell cultures. J Neurobiol 38(1): 65-81.[Pubmed]

109.Wang TW, Zhang H, Parent JM (2005) Retinoic acid regulates postnata neurogenesis in the murine subventricular zone-olfactory bulb pathway. Development 132(12): 2721-2732.[Pubmed] 
Citation: Oyarce K, Nualart F (2014) Unconventional Neurogenic Niches and Neurogenesis Modulation by Vitamins. J Stem Cell Res Ther 4: 184. doi:10.4172/2157-7633.1000184

Page 10 of 11

110. Balkan W, Colbert M, Bock C, Linney E (1992) Transgenic indicator mice for studying activated retinoic acid receptors during development. Proc Natl Acad Sci U S A 89(8): 3347-3351. [Pubmed]

111. Rossant J, Zirngibl R, Cado D, Shago M, Giguere V (1991) Expression of a retinoic acid response element--hsplacZ transgene defines specific domains of transcriptional activity during mouse embryogenesis. Genes Dev 5(8): 1333-1344.[Pubmed]

112. Jacobs S, Lie DC, DeCicco KL, Shi Y, DeLuca LM, et al. (2006) Retinoic acid is required early during adult neurogenesis in the dentate gyrus. Proc Natl Acad Sci U S A 103(10): 3902-3907.[Pubmed]

113. McCaffery P, Koul O, Smith D, Napoli JL, Chen N, et al. (2004) Ethanol increases retinoic acid production in cerebellar astrocytes and in cerebellum. Brain Res Dev Brain Res 153(2): 233-241.[Pubmed]

114. Yamamoto M, McCaffery P, Dräger UC (1996) Influence of the choroid plexus on cerebellar development: analysis of retinoic acid synthesis. Brain Res Dev Brain Res 93(1-2): 182-190.[Pubmed]

115. Haskell GT, LaMantia AS (2005) Retinoic acid signaling identifies a distinct precursor population in the developing and adult forebrain. J Neurosci 25(33): 7636-7647.[Pubmed]

116. Touyarot $K$, Bonhomme D, Roux $P$, Alfos $S$, Lafenêtre $P$, et al. (2013) A midlife vitamin $A$ supplementation prevents age-related spatial memory deficits and hippocampal neurogenesis alterations through CRABP-I. PLoS One 8(8): e72101.[Pubmed]

117. Misner DL, Jacobs S, Shimizu Y, de Urquiza AM, Solomin L, et al. (2001) Vitamin A deprivation results in reversible loss of hippocampal long-term synaptic plasticity. Proc Natl Acad Sci U S A 98(20): 11714-11719.[Pubmed]

118. Cocco S, Diaz G, Stancampiano R, Diana A, Carta M, et al. (2002) Vitamin A deficiency produces spatial learning and memory impairment in rats. Neuroscience 115(2): 475-482.[Pubmed]

119. Bonnet E, Touyarot K, Alfos S, Pallet V, Higueret P, et al. (2008) Retinoic acid restores adult hippocampal neurogenesis and reverses spatial memory deficit in vitamin A deprived rats. PLoS One 3(10): e3487.[Pubmed]

120. Goodman T, Crandall JE, Nanescu SE, Quadro L, Shearer K, et al. (2012) Patterning of retinoic acid signaling and cell proliferation in the hippocampus. Hippocampus 22: 2171-2183.[Pubmed]

121. Helfer G, Ross AW, Russell L, Thomson LM, Shearer KD, et al. (2012) Photoperiod regulates vitamin $A$ and $W n t / \hat{I}^{2}$-catenin signaling in $\mathrm{F} 344$ rats. Endocrinology 153(2): 815-824.[Pubmed]

122. Shearer KD, Goodman TH, Ross AW, Reilly L, Morgan PJ, et al. (2010) Photoperiodic regulation of retinoic acid signaling in the hypothalamus. $J$ Neurochem 112(1): 246-257.[Pubmed]

123. Krezel W, Kastner P, Chambon $P$ (1999) Differential expression of retinoid receptors in the adult mouse central nervous system. Neuroscience 89(4): 1291-1300.[Pubmed]

124. Rice ME (2000) Ascorbate regulation and its neuroprotective role in the brain. Trends Neurosci 23(5): 209-216.[Pubmed]

125. Nishikimi M, Fukuyama R, Minoshima S, Shimizu N, Yagi K (1994) Cloning and chromosomal mapping of the human nonfunctional gene for L-gulonogamma-lactone oxidase, the enzyme for L-ascorbic acid biosynthesis missing in man. J Biol Chem 269(18): 13685-13688.[Pubmed]

126. Harrison FE, May JM (2009) Vitamin C function in the brain: vital role of the ascorbate transporter SVCT2. Free Radic Biol Med 46(6): 719-730.[Pubmed]

127. Robertson WV, Hewitt $J$ (1961) Augmentation of collagen synthesis by ascorbic acid in vitro. Biochim Biophys Acta 49: 404-406.[Pubmed]

128. May JM, Qu ZC, Meredith ME (2012) Mechanisms of ascorbic acid stimulation of norepinephrine synthesis in neuronal cells. Biochem Biophys Res Commun 426(1): 148-152.[Pubmed]

129. May JM, Qu ZC, Nazarewicz R, Dikalov S (2013) Ascorbic acid efficiently enhances neuronal synthesis of norepinephrine from dopamine. Brain Res Bull 90: 35-42.[Pubmed]

130. Meredith ME, May JM (2013) Regulation of embryonic neurotransmitter and tyrosine hydroxylase protein levels by ascorbic acid. Brain Res 1539: 7-14. [Pubmed]

131. Rebouche CJ (1991) Ascorbic acid and carnitine biosynthesis. Am J Clin Nutr 54(6 Suppl): 1147S-1152S.[Pubmed]
132. Glembotski CC (1987) The role of ascorbic acid in the biosynthesis of the neuroendocrine peptides alpha-MSH and TRH. Ann N Y Acad Sci 498: 54-62. [Pubmed]

133. Rebec GV, Pierce RC (1994) A vitamin as neuromodulator: ascorbate release into the extracellular fluid of the brain regulates dopaminergic and glutamatergic transmission. Prog Neurobiol 43(6): 537-565.[Pubmed]

134.Sandstrom MI, Rebec GV (2007) Extracellular ascorbate modulates glutamate dynamics: role of behavioral activation. BMC Neurosci 8: 32.[Pubmed]

135. Eldridge CF, Bunge MB, Bunge RP, Wood PM (1987) Differentiation of axon-related Schwann cells in vitro. I. Ascorbic acid regulates basal lamina assembly and myelin formation. J Cell Biol 105(2): 1023-1034.[Pubmed]

136. Chang BJ, Jang BJ, Son TG, Cho IH, Quan FS, et al. (2012) Ascorbic acid ameliorates oxidative damage induced by maternal low-level lead exposure in the hippocampus of rat pups during gestation and lactation. Food Chem Toxicol 50(2): 104-108.[Pubmed]

137. Guaiquil VH, Vera JC, Golde DW (2001) Mechanism of vitamin C inhibition of cell death induced by oxidative stress in glutathione-depleted HL-60 cells. J Biol Chem 276(44): 40955-40961.[Pubmed]

138. Harrison FE, Meredith ME, Dawes SM, Saskowski JL, May JM (2010) Low ascorbic acid and increased oxidative stress in gulo(-/-) mice during development. Brain Res 1349: 143-152.[Pubmed]

139. Nualart FJ, Rivas CI, Montecinos VP, Godoy AS, Guaiquil VH, et al. (2003) Recycling of vitamin C by a bystander effect. J Biol Chem 278(12): 1012810133.[Pubmed]

140. Carney MW (1990) Vitamin deficiency and mental symptoms. Br J Psychiatry 156: 878-882.[Pubmed]

141. Ginter E (2007) Chronic vitamin C deficiency increases the risk of cardiovascular diseases. Bratisl Lek Listy 108(9): 417-421. [Pubmed]

142. Magiorkinis E, Beloukas A, Diamantis A (2011) Scurvy: past, present and future. Eur J Intern Med 22(2): 147-152.[Pubmed]

143. Lee JY, Chang MY, Park CH, Kim HY, Kim JH, et al. (2003) Ascorbate-induced differentiation of embryonic cortical precursors into neurons and astrocytes. J Neurosci Res 73(2): 156-165.[Pubmed]

144.Pasonen-Seppanen S, Suhonen TM, Kirjavainen M, Suihko E, Urtti A, et al. (2001) Vitamin C enhances differentiation of a continuous keratinocyte cell line (REK) into epidermis with normal stratum corneum ultrastructure and functional permeability barrier. Histochem Cell Biol 116(4): 287-297.[Pubmed]

145. Qiao H, May JM (2009) Macrophage differentiation increases expression of the ascorbate transporter (SVCT2). Free Radic Biol Med 46(8): 1221-1232. [Pubmed]

146. Savini I, Catani MV, Rossi A, Duranti G, Melino G, et al. (2002) Characterization of keratinocyte differentiation induced by ascorbic acid: protein kinase $C$ involvement and vitamin C homeostasis. J Invest Dermatol 118(2): 372-379. [Pubmed]

147. Takahashi T, Lord B, Schulze PC, Fryer RM, Sarang SS, et al. (2003) Ascorbic acid enhances differentiation of embryonic stem cells into cardiac myocytes. Circulation 107(14): 1912-1916.[Pubmed]

148. Takamizawa S, Maehata Y, Imai K, Senoo H, Sato S, et al. (2004) Effects of ascorbic acid and ascorbic acid 2--phosphate, a long--acting vitamin $C$ derivative, on the proliferation and differentiation of human osteoblast-like cells. Cell Biol Int 28(4): 255-265.[Pubmed]

149. Wu X, Itoh N, Taniguchi T, Hirano J, Nakanishi T, et al. (2004) Stimulation of differentiation in sodium-dependent vitamin $\mathrm{C}$ transporter 2 overexpressing MC3T3-E1 osteoblasts. Biochem Biophys Res Commun 317(4): 1159-1164. [Pubmed]

150.Wu X, Zeng LH, Taniguchi T, Xie QM (2007) Activation of PKA and phosphorylation of sodium-dependent vitamin $\mathrm{C}$ transporter 2 by prostaglandin E2 promote osteoblast-like differentiation in MC3T3-E1 cells. Cell Death Differ 14(10): 1792-1801.[Pubmed]

151.Yan J, Studer L, McKay RD (2001) Ascorbic acid increases the yield of dopaminergic neurons derived from basic fibroblast growth factor expanded mesencephalic precursors. J Neurochem 76(1): 307-311.[Pubmed]

152. Shin DM, Ahn JI, Lee KH, Lee YS, Lee YS (2004) Ascorbic acid responsive genes during neuronal differentiation of embryonic stem cells. Neuroreport 15(12): 1959-1963.[Pubmed] 
Citation: Oyarce K, Nualart F (2014) Unconventional Neurogenic Niches and Neurogenesis Modulation by Vitamins. J Stem Cell Res Ther 4: 184. doi:10.4172/2157-7633.1000184

Page 11 of 11

153. Yu DH, Lee KH, Lee JY, Kim S, Shin DM, et al. (2004) Changes of gene expression profiles during neuronal differentiation of central nervous system precursors treated with ascorbic acid. J Neurosci Res 78(1): 29-37.[Pubmed]

154. Ghosal A, Subramanian VS, Said HM (2011) Role of the putative N-glycosylation and PKC-phosphorylation sites of the human sodium-dependent multivitamin transporter (hSMVT) in function and regulation. Biochim Biophys Acta 1808(8): 2073-2080.[Pubmed]

155. May JM (2011) The SLC23 family of ascorbate transporters: ensuring that you get and keep your daily dose of vitamin C. Br J Pharmacol 164(7): 1793-1801. [Pubmed]

156. Savini I, Rossi A, Pierro C, Avigliano L, Catani MV (2008) SVCT1 and SVCT2: key proteins for vitamin C uptake. Amino Acids 34(3): 347-355.[Pubmed]

157. Subramanian VS, Marchant JS, Reidling JC, Said HM (2008) N-Glycosylation is required for $\mathrm{Na}+$-dependent vitamin $\mathrm{C}$ transporter functionality. Biochem Biophys Res Commun 374(1): 123-127.[Pubmed]

158. Tsukaguchi H, Tokui T, Mackenzie B, Berger UV, Chen XZ, et al. (1999) A family of mammalian $\mathrm{Na}+$-dependent L-ascorbic acid transporters. Nature 399(6731): 70-75.[Pubmed]

159. Qiu S, Li L, Weeber EJ, May JM (2007) Ascorbate transport by primary cultured neurons and its role in neuronal function and protection against excitotoxicity. J Neurosci Res 85(5): 1046-1056.[Pubmed]

160. Caprile T, Salazar K, Astuya A, Cisternas P, Silva-Alvarez C, et al. (2009) The Na+-dependent L-ascorbic acid transporter SVCT2 expressed in brainstem cells, neurons, and neuroblastoma cells is inhibited by flavonoids. J Neurochem 108(3): 563-577.[Pubmed]

161. Castro M, Caprile T, Astuya A, Millán C, Reinicke K, et al. (2001) High-affinity sodium-vitamin C co-transporters (SVCT) expression in embryonic mouse neurons. J Neurochem 78(4): 815-823.[Pubmed]

162. Mun GH, Kim MJ, Lee JH, Kim HJ, Chung YH, etal. (2006) Immunohistochemical study of the distribution of sodium-dependent vitamin $\mathrm{C}$ transporters in adult rat brain. J Neurosci Res 83(5): 919-928.[Pubmed]

163. Ulloa V, Garcia-Robles M, Martinez F, Salazar K, Reinicke K, et al. (2013) Human choroid plexus papilloma cells efficiently transport glucose and vitamin C. J Neurochem 127(3): 403-414.[Pubmed]

164. García Mde L, Salazar K, Millán C, Rodríguez F, Montecinos H, et al. (2005) Sodium vitamin C cotransporter SVCT2 is expressed in hypothalamic glial cells. Glia 50(1): 32-47.[Pubmed]

165. Biondi C, Pavan B, Dalpiaz A, Medici S, Lunghi L, et al. (2007) Expression and characterization of vitamin $C$ transporter in the human trophoblast cell line HTR-8/SVneo: effect of steroids, flavonoids and NSAIDs. Mol Hum Reprod 13(1): 77-83.[Pubmed]

166. Fujita I, Hirano J, Itoh N, Nakanishi T, Tanaka K (2001) Dexamethasone induces sodium-dependant vitamin $\mathrm{C}$ transporter in a mouse osteoblastic cell line MC3T3-E1. Br J Nutr 86(2): 145-149.[Pubmed]

167. Lutsenko EA, Carcamo JM, Golde DW (2004) A human sodium-dependent vitamin $C$ transporter 2 isoform acts as a dominant-negative inhibitor of ascorbic acid transport. Mol Cell Biol 24(8): 3150-3156.[Pubmed]

168. Tveden-Nyborg $\mathrm{P}$, Johansen LK, Raida Z, Villumsen CK, Larsen JO, et al. (2009) Vitamin C deficiency in early postnatal life impairs spatial memory and reduces the number of hippocampal neurons in guinea pigs. Am J Clin Nutr 90(3): 540-546.[Pubmed]

169. Tveden-Nyborg P, Vogt L, Schjoldager JG, Jeannet N, Hasselholt S, et al. (2012) Maternal vitamin C deficiency during pregnancy persistently impairs hippocampal neurogenesis in offspring of guinea pigs. PLoS One $7(10)$ : e48488.[Pubmed]

170. Pastor P, Cisternas P, Salazar K, Silva-Alvarez C, Oyarce K, et al. (2013) SVCT2 vitamin C transporter expression in progenitor cells of the postnatal neurogenic niche. Front Cell Neurosci 7: 119.[Pubmed]

171. Webb AR, Engelsen O (2006) Calculated ultraviolet exposure levels for a healthy vitamin D status. Photochem Photobiol 82(6): 1697-1703.[Pubmed]
172. Basit S (2013) Vitamin $\mathrm{D}$ in health and disease: a literature review. $\mathrm{Br} J$ Biomed Sci 70: 161-172.[Pubmed]

173. Christakos S, Ajibade DV, Dhawan P, Fechner AJ, Mady LJ (2010) Vitamin D metabolism. Endocrinol Metab Clin North Am 39(2): 243-253.[Pubmed]

174. Christakos S, Dhawan P, Ajibade D, Benn BS, Feng J, et al. (2010) Mechanisms involved in vitamin D mediated intestinal calcium absorption and in non-classical actions of vitamin D. J Steroid Biochem Mol Biol 121(1-2): 183-187.[Pubmed]

175. Deluca HF, Cantorna MT (2001) Vitamin D: its role and uses in immunology. FASEB J 15(14): 2579-2585.[Pubmed]

176. Eyles DW, Smith S, Kinobe R, Hewison M, McGrath JJ (2005) Distribution of the vitamin $\mathrm{D}$ receptor and 1 alpha-hydroxylase in human brain. $\mathrm{J}$ Chem Neuroanat 29(1): 21-30.[Pubmed]

177. Féron F, Burne TH, Brown J, Smith E, McGrath JJ, et al. (2005) Developmental Vitamin D3 deficiency alters the adult rat brain. Brain Res Bull 65(2): 141-148. [Pubmed]

178. Ko P, Burkert R, McGrath J, Eyles D (2004) Maternal vitamin D3 deprivation and the regulation of apoptosis and cell cycle during rat brain development. Brain Res Dev Brain Res 153(1): 61-68.[Pubmed]

179. Harms LR, Burne TH, Eyles DW, McGrath JJ (2011) Vitamin D and the brain Best Pract Res Clin Endocrinol Metab 25(4): 657-669.[Pubmed]

180. Kesby JP, Cui X, Ko P, McGrath JJ, Burne TH, et al. (2009) Developmental vitamin $\mathrm{D}$ deficiency alters dopamine turnover in neonatal rat forebrain Neurosci Lett 461(2): 155-158.[Pubmed]

181. Kesby JP, Cui X, O'Loan J, McGrath JJ, Burne TH, et al. (2010) Developmenta vitamin $D$ deficiency alters dopamine-mediated behaviors and dopamine transporter function in adult female rats. Psychopharmacology (Berl) 208(1): 159-168.[Pubmed]

182. Wilkins CH, Sheline YI, Roe CM, Birge SJ, Morris JC (2006) Vitamin D deficiency is associated with low mood and worse cognitive performance in older adults. Am J Geriatr Psychiatry 14(12): 1032-1040.[Pubmed]

183. Carlberg C, Seuter S (2009) A genomic perspective on vitamin D signaling Anticancer Res 29(9): 3485-3493.[Pubmed]

184. Samuel S, Sitrin MD (2008) Vita min D's role in cell proliferation and differentiation. Nutr Rev 66(10 Suppl 2): S116-S124.[Pubmed]

185. Cui X, McGrath JJ, Burne TH, Mackay-Sim A, Eyles DW (2007) Maternal vitamin $\mathrm{D}$ depletion alters neurogenesis in the developing rat brain. Int $\mathrm{J}$ Dev Neurosci 25(4): 227-232.[Pubmed]

186. Prüfer K, Veenstra TD, Jirikowski GF, Kumar R (1999) Distribution of 1,25-dihydroxyvitamin D3 receptor immunoreactivity in the rat brain and spinal cord. J Chem Neuroanat 16(2): 135-145.[Pubmed]

187.Zhu Y, Zhou R, Yang R, Zhang Z, Bai Y, et al. (2012) Abnormal neurogenesis in the dentate gyrus of adult mice lacking 1,25-dihydroxy vitamin D3 $(1,25$ $(\mathrm{OH}) 2$ D3). Hippocampus 22(3): 421-433.[Pubmed] 